\title{
Utilisation of Tropical Australia
}

$I^{\mathrm{N}}$ discussions relating to white settlement in Australia, reference is often made to the scant population in the Northern Territory in comparison with the dense population of Java, though portions of Java are said to possess similar soil and climatic conditions to the Northern Territory. Sir David Rivett, on behalf of the Commonwealth Council for Scientific and Industrial Research, and with the assistance of the British Consul at Batavia, has made an inquiry into this matter and has been supplied with information by Dr. J. G. B. Beumée, Chief of the Agriculture and Fishery Service, Batavia. Dr. Beumée reports as follows:

"The driest regions of Eastern Java and the Lesser Sunda Islands are only comparable to the more rainy stations from your table [information supplied from Australia]. The rainfall is quite insufficient for an intensive native agriculture. In the district as far as situated on the Islands of Bali and of Lombok, extensive areas are suitable for the growing of paddy, as the rivers from the high volcanoes, which receive much more rain throughout the year, contain sufficient quantities of water for irrigation purposes.

"Only in the dry district of Java where one river brings only sufficient irrigation water, sugar-cane is grown by one European firm, otherwise the scanty native population get a living by cultivating maize, millets, cotton, several drought-resisting beans, and locally by an extensive raising of cattle and horses. The climatic conditions are not suitable for introducing agriculture along Western methods."

Java and Madura are about twice the size of Tasmania, approximately 50,000 square miles in area, and contain about thirty-eight million inhabitants who are pressing on the means of subsistence. This density, which averages about 750 to the square mile, is exceeded in the northern and fertile portion of the island. Several regions have a dry climate and most of these are situated on the lesser Sunda Islands (and the eastern end of Java).

Eight districts are indicated where the rainfall varies from about 50 to 90 inches per annum, but with a period of relatively dry months similar to the conditions in the Northern Territory and parts of coastal Queensland.

In a subsequent letter, dated March 2, 1936, Dr. Beumée furnishes a table showing the population in these dry areas, so far as practicable, and writes as follows :

"The influence of the abundance of irrigation-water on the denseness of the native population is very striking. The districts 2 and 3 on the lower southern slopes of the volcanoes on Bali have the densest population by far. Since very long times the natives there have made and kept in perfect order the necessary arrangements for the distribution of the water as to obtain the highest profit from irrigating their paddy-fields.

"District 8 also has a rather dense population (the average for the whole of Java and Madura being 310 per square kilometer) which population as a matter of fact can get their living there only by the availability of irrigation water."

Some of these are supplied with water by irrigation from the volcanoes of Bali, and they carry a large population. But in other districts the population per square mile varies from 65 to 200 , whereas in the dry districts which have irrigation it rises to 750 .

It is obvious that even with this enormous popula. tion pressure, the dry areas cannot be densely peopled. In Northern Australia, apart from coastal Queensland where the rainfall is not as good and there can be no irrigation, anything like a dense population is out of the question-especially when the population pressure is limited to less than seven million people.

\section{Copelata of the Terra Nova Expedition}

GUPPLEMENTING his report on the Doliolids (see $\checkmark$ Nature of July 21, 1934) Prof. Garstang now deals with the Appendicularians (Report on the Tunicata. Part 2, Copelata. Prof. W. Garstang and Dr. Elizabeth Georgeson. British Antarctic (Terra Nova) Expedition, 1910. Natural History Report. Zoology. 4, No. 8, 1935. British Museum (Natural History), price 1s. 6d.). These are from the Atlantic, South Pacific, north-west of New Zealand and the Antarctic, and are all Oikopleurids. Out of 2,000 specimens from thirty-four stations, not less than 1,900 belong to the two species $O$. longicauda, dominating the warm waters of the Atlantic and South Pacific, and $O$. valdivice, dominating the Antarctic waters. O. longicauda is of world-wide value as a warm-water indicator, and its dominance in the Atlantic and South Pacific samples and absence in the antaretic stations bears this out.

In the recent report of the Tunicata from the Great Barrier Reef (F. S. Russell and J. S. Colman, Scientific Reports, 2, No. 7) the authors find also that two species predominate, one being $O$. longicauda, the characteristic species for the warm-water region of the Atlantic, Pacific and Indian Oceans, abundant both in coastal waters and the open sea, and 0 . rufescens, which is a true tropical form, scarcer in the open ocean than in the coastal region, and more frequent in the Indian Ocean than in the Atlantic. In $O$. valdivice a very small proportion are mature before the final stage of growth, and the records suggest a short breeding season late in the Antarctic summer. A new species of Folia ( $F$. gigas) is created for a single specimen from the Antarctic, taken in a net towed (nominally) at a depth of 80 metres, differing in several anatomical points as well as in much greater size from Lohmann's Folia gracilis. This had probably drifted into Antarctic waters from the tropical Pacific. The Stegosomas are now recognised as essentially epiplanktonic and tropical. Three specimens of Pelagopleura magna are interesting, and the presence of food-remains in them seems to prove Lohmann's view that it is a natural inhabitant of antarctic deep water, to which it appears to be confined. 